\title{
近世在郷寺社普請における明王太郎の棟梁職の獲得とその背景について ACQUISITION OF LEADERSHIP POSITION IN CONSTRUCTION OF TEMPLE AND SHRINE BY MYOUO-TARO AND ITS SOCIAL BACKGROUND AT SAGAMI-KOKU IN THE PRE-MODERN PERIOD
}

\author{
山岸吉弘*
}

\section{Yoshihiro YAMAGISHI}

\begin{abstract}
Myouo-taro built as chief constructor many temples and shrines in Sagami-koku region in the pre-modern period. He enlarged his sphere of construction making close relationships with its social background. There were some factors for expansion of his construction activities around Mt.Ōyama. This paper points out three factors: First, he took many pupils, and they got works for him. Second, the people named "Oshi"(guides) lived in Mt.Ōyama had huge network for Ōyama-dera temple. Third, the people named "Danka"(supporters) had common information about Mt.Ōyama.
\end{abstract}

Keywords : Sagami-koku in the pre-modern period, Mt. Ōyama, construction of temple and shrine, Daiku Toryo, Myouo-taro, region and community 近世相模国, 大山, 在郷寺社普請, 大工棟梁, 明王太郎, 地域と共同体

1.はじめに

明王太郎は江戸時代を通じて大工棟梁として活躍し、数多くの在 郷寺社の造営を手掛けたことが知られている ${ }^{11}$ 。それら寺社の所在 地は、明王太郎の居住地がある相模国や隣国の武蔵国が中心となる ものの、広い範囲に亘って点在し分散している ${ }^{2)}$ 。明王太郎は相州 大山（伊勢原市大山）を活動の拠点としていながらも、それより隔 たりのある各地において「棟梁職」を獲得し ${ }^{3)}$ 、大工棟梁として普 請に従事することができた背景には、相応の特別な要因を想定させ る。そこには、明王太郎と在郷寺社を結び付ける媒体の存在を仮定 しなければならないだろう。

これまでにも、在地の大工に関して多くの論考が発表されており、 個人の活動形態や組織としての仕組み、それが及ぶ圈域などが検討 されている。例えば、気仙沼大工・下山大工・淡路大工・長州大工 といった大工集団の存在が知られ、それぞれの特色が指摘されてい る ${ }^{4)}$ 。特に、大工と施主の慗がりを積極的に論じた論考もあり、注目 される ${ }^{5)}$ 。また、武蔵国の社寺造営を考察の対象にした論考は、明 王太郎の活動と地域を同じくすることから参照すべきものとなる ${ }^{6)}$ 。

明王太郎が居住した大山周辺の集落では、大工等の職業の別によっ て結び付く集団は組織されず、大山寺やその他の権力に寄って仕事 を確保するということもなかったようである ${ }^{7)}$ 。明王太郎は自ら行 動して大山寺造営に参加することに成功し、その立場や役所を築き 上げていったことが明らかとなっている ${ }^{8)}$ 。そこには、ある種の都 市的な個人主義とでも呼べる側面を有しており、それが明王太郎の 活動形態や大山寺周辺の地域社会の特色とも言えるだろう。
本稿では、明王太郎が在郷寺社の普請で棟梁職を獲得するに至る までの過程を辿り、両者を繋いだ要素を明らかにすることを目的に している。また、それら要素が機能する仕組みや、関係性を成立さ せるための構造を検討することも併せて試みる。

\section{2. 棟梁職の獲得と弟子（氏子大工）}

明王太郎が棟梁職を獲得する過程を、㔖㔖神社（中郡二宮町山茜）

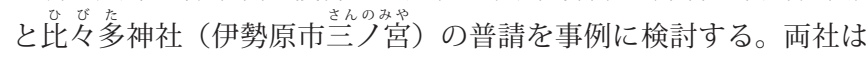
相模国の二之宮と三之宮で、共に延喜式に記載のある古社である。

\section{（1）川勾神社の普請}

明王太郎は、天明七年（1787）に川勾神社の普請を行っている。 その時に掲げられた棟札には、く手中明王太良忌部景直 / 景喜 >の 他に ${ }^{9)}$ 、明王太郎の門人である $<$ 石井庄助 / 神崎吉左衛門 / 小川庄蔵 / 守屋傳八 $>$ の四人の名前が記されている ${ }^{10)}$ 。これより、この普請 は明王太郎の一門によって行われたことが想定され ${ }^{11)}$ 、特に石井庄 助は安永元年（1772）に奉公に入って以来の一の弟子である ${ }^{12) 。 ~}$

明王太郎（景直）は、安永九年（1780）秋に社殿の下絵図を描い ている ${ }^{13)}$ 。二年後の天明二年（1782）九月下旬にも下図と木寄せを 作成し、普請の準備を進める ${ }^{14)}$ 。翌天明三年 (1783) 二月十一日に 手斧始めが行われ、普請が開始されるに至る ${ }^{15)}$ 。主な大工の出仕延 べ人数と期間は、それぞれ九百六十人と十ヶ月であった ${ }^{16)}$ 。

川勾神社には、上記のような大規模な普請とは別に日常的な修繥 などを任せる大工との付き合いもあり、宮司の二見神太郎が日常を 記録した日記（以後は「川勾神社日記」と表記）にはそれら出入り

木稿は，部分的に以下の既発表内容を含んでいる。山岸吉弘「大山の枆に居住する明王太郎の活動領域－明王大郎の在郷寺社における普請役の獲得と従事について(川勾神社を 中心として) - 」『日本建築学会関東支部研究報告集 II 』2007年度, 日本建築学会, 2008.02(東京・2008年 3 月)。山岸吉弘「明王太郎による大山近郷の寺社普請(円通寺を中心とし て) - 明王太郎の在郷寺社における普請役の獲得について：その 3 -」『日本建築学会関東支部研究報告集 II 』2008年度, 日本建築学会, 2009.02(東京・2009年 3 月)。

* 早稲田大学理工学研究所 助手 ·修士 (建築学) Research Assoc., Research Institute for Science and Engineering, WASEDA University, M. Architecture 
の大工の名前が頻繁に登場する ${ }^{17)}$ 。例えば、「作料」や「仕ちん」と して、「金式朱」や「金壱分」といった比較的に小額の報酬が、大工 に対して度々に支払われている ${ }^{18)}$ 。抢そらく、日頃の身の回りにあ る簡単な仕事に対しての報酬なのであろう。日記が記される期間の 内に拈いて、天明・寛政期では忠七という大工がその役を ${ }^{19)}$ 、文化 から文久期では周助という大工が ${ }^{20)}$ 、天保・弘化期では佐吉という 大工が ${ }^{21)}$ 、それぞれ担っている。いずれも越地（中郡二宮町山西） の大工であり、川勾神社と大工町としての当地との関係が想定され る ${ }^{22)}$ 。一方で、天明期には本殿の普請が行われているのであり、そ の時に棟梁を務めた明王太郎などの大工の名前は棟札に記録されて いるが、一方で、越路の大工である忠七の名前は見当たらない。以 上のことから、本殿の普請が行われた当時において、二つの異なる 性質の仕事が発生し、別々の大工がそれに従事していたことが分か る。また、川勾神社と越路大工は、より日常的な関係性を成立させ ていたことも同時に理解される。

天明期の普請が終わった後の寛政十一年（1799）一月十六日に、 二見神太郎は明王太郎宛に書状を送り、当社明神の普請のために図 面を携えて来訪することを要請している ${ }^{23)}$ 。同月二十六日には二見 神太郎が年始の挨拶回りで大山へ向かい、明王太郎宅を直接に訪問 している。そこでは叶（景喜の別称）と対面しており、普請の話し 合いが行われ、翌二月二十日頃に明王太郎本人の川勾神社への来訪 が話し合いでまとめられた ${ }^{24)}$ 。その後、明王太郎は弟子と共に川勾 神社を訪れ、改めて図面を届けており、普請の準備が進められる ${ }^{25)}$ 。

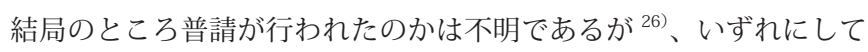
も川勾神社は明王太郎に普請を依頼し、明王太郎もそれに応じて図 面を作成しており、依然として川勾神社と明王太郎との間柄は保た れ、かつ密接な関係にあった。

\section{(2) 弟子と氏子大工}

それから約半世紀を経た後の嘉永五年（1852）に、大山の麓に位 置する比々多神社の拝殿の普請が企図されている。隣村の稁原村（伊 勢原市三ノ宮）の石井五郎左衛門が発起人となって普請は発案され、 川勾神社出入りの大工である周助（前述の人物とは別の越路大工） に絵図面の作成が指示された ${ }^{27)}$ 。嘉永五年 (1852) 十月一日に、周助 は伊勢原（伊勢原市伊勢原・桜台）の大工である七蔵と共に川勾神 社を訪れている。その日は川勾神社で会合が催され、比々多神社の 周辺にある村々から名主が集まっていた。その場で二見神太郎が棟 梁を周助に任せることを、それぞれの名主に承知させたようである。 その二日後の三日には、糟屋村（伊勢原市上粕屋・卡糟屋）の名主 宅を周助に案内させて、二見神太郎が見舞っている。その目的は明 記されないものの、過日の会合での様子を踏まえれば、およそ同様 の内容と見当が付くだろう。周助が比々多神社の普請役を獲得する ためには、少なからず川勾神社という後ろ盾を必要としていた。

このように、周助が川勾神社の協力をあからさまに必要としたの は、明王太郎と棟梁の座を争うことになったためである。二見神太 郎が糟屋村に向かう数日前の九月三十日に、明王太郎は神戸村（伊 勢原市神声・鈴势）の栄蔵の取持ちによって、村役人を迴っている。 川勾神社は明王太郎との縁が深いが、今回は後見職を務める周助を 推挙する。一方で、明王太郎を棟梁職にと周旋するのは、弟子や比久 多神社の氏子を務める大工である。嘉永五年（1852）十一月付け の書状が、これら氏子大工や弟子から発起人の石井五郎左衛門に宛
てて提出されており、明王太郎を棟梁に任命することを請願してい る ${ }^{28)}$ 。その内容は極めて氏子大工や弟子らしいもので、金銭のため ではなく、氏神であるところの比々多神社の普請に、明王太郎を棟 梁として自らも参加することが願いであると主張している。

翌嘉永六年（1853）四月二十日に比々多神社神主と氏子総代の栗 原村名主清五郎が川勾神社を訪れ、氏子が役人を交えての協議を行 いそその際には両棟梁とも相談をしたことを報告している ${ }^{29)}$ 。同年 八月二十日に神主と神戸村の栄蔵が川勾神社を訪れ、明王太郎と周 助が共に棟梁を務めることを提案し、問題の沈静化を図る。その後 の展開は記録がなく不明であるが ${ }^{30)}$ 、一連の騒動より諸事は複雑な 関係性の上に成立していたことが分かる。

(3)まとめ

明王太郎は、比々多神社の普請における棟梁職を巡って、川勾神 社の出入りの大工と争うこととなる。その際に、明王太郎を棟梁に 推したのが弟子や氏子大工であった。それら弟子や氏子大工は、明 王太郎の門人であることを積極的に主張し、それを建前として争う。 以上より、明王太郎が普請を獲得するにあたって、直接的には弟子 や氏子大工の働きによるものであり、間接的には明王太郎という大 工棟梁の存在そのものが機能していた。

\section{3. 棟梁職の獲得と弟子（在郷大工）}

明王太郎が在郷寺社の普請で棟梁職を獲得するということにおい て、少なからず弟子の存在が作用している。弟子によって明王太 郎が棟梁職を得る具体的な事例を、寺山村 (秦野市寺山) にある 离通寺の普請において検討する。

\section{（1）円通寺の普請}

円通寺は嘉永二年 (1849)に灭災に遭い、本堂や庫裏を焼失した ${ }^{31}$ 。 七年後の安政三年（1856）に、明王太郎が本堂の普請を請け負うこ とになる ${ }^{32)}$ 。この契約が交わされるまでの経緯が簡単に記録され、 おおよそを知ることができる ${ }^{33)}$ 。それによると、明王太郎と依頼主 の間を弟子が仲介していたことが確認できる。

その弟子は萇毛（伊勢原市襄毛）の大工で、弥市と称する。萇毛 は大山の西側の麓に位置し、大山御師も多数居住した ${ }^{34)}$ 。弥市はそ れより明王太郎の下へ弟子大りし、年季が明けて郷里の萇毛に戻っ たのであろう。その後は一人前の大工として活躍していた。

弥市は、隣村の寺山村に境内を構える円通寺において普請がある ことを聞き付け、大工棟梁として明王太郎を推薦した。それを受けて、 安政三年（1856）九月に<重役 $>$ の武源右衛門安清とその $<$ 弟子 $>$ の善右衛門より明王太郎に申し越しがあり、同月六日には、早速に 明王太郎が同人宅へ罷り出ている。翌七日の朝には世話人と対面し、 同日夜には＜証文＞を交わし、本堂の仕様と金高の＜議定書 $>$ を作 成している。翌八日には、武源右衛門安清と金子について約定して 村を後にする。こうして、明王太郎は円通寺本堂の普請を手がける こととなった。別の控には、安政三年（1856）九月四日付けで、<相 州大住群寺山村セン宗エンツウ寺様ミノゲ弟子相原弥一事取持 $>$ と その経緯が明瞭に記録されており、弟子が明王太郎と円通寺の間を 取り持っていたことが分かる ${ }^{35)}$ 。

(2) 弟子の「弥市」

円通寺本堂の普請を明王太郎が請け負うに当たっては弟子の弥市 の存在が大きく、棟梁と依頼主を繋ぐ役割を果たしていた。弥市は、 
仲介役というだけでなく、本職の大工としても仕事に加わっていた と考えられる。これ以外の明王太郎が手掛ける普請において、弥市 の名前が記録に残されている。

円通寺の普請が行われる十六年前の天保十一年（1840）に、弥市 は沼目村 (伊勢原市沼目) にある天王宮の普請に参加している ${ }^{36)}$ 。 そこでの、弥市の出仕延べ人数は百九十三人となり、明王太郎の 七十三人よりも多く、大工延べ総数千六百十三人の内の一割強を占 める。仕事を進めるにあって、弥市が中心的な役割を担う大工の一 人として位置付けられていたことが想定される。それより弥市の立 場が椝われ、おそ覚わらは年季の最中にあり、一門に属する大工とし て普請に携わっていたのであろう ${ }^{37)}$ 。

沼目村天王宮普請から十三年後に、再び明王太郎が手掛けた普請 に参加している。しかし、このときは一門にいる弟子としてのこと ではなく、独立した一人前の大工としてそれに加わっていたようで ある。嘉永六年 (1853) に厚木町 (厚木市厚势町) にある天王宮の

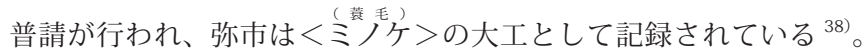
弥市の出自は萇毛にあるが、通常では弟子の出身地を名前と共に併 記することはない。しかし、出身を併記し、人物を特定する場合が あり、おそらくは一閏でない大工という区別であると考えられる。 そのような大工や職人は、<秋山 >の長治郎や<飯山匠 >の忠次郎、 ＜田中木挽 $>$ の菊治郎などが挙げられ、出身地名が記録されている。 弥市も十三年前は弟子であったが、年季が明けて帰郷し、その後に 再び明王太郎一門の普請に参加することとなっては、年季奉公人と してではなく、自立した大工として任に当たることになった。

(3) 明王太郎の弟子

明王太郎は多く弟子を取り、それは年季勤めの奉公人として受け 入れられている。入門の際には「弟子奉公人請状」が作成され、身 元引受け人から明王太郎に宛てて提出される。それら請状の一部が 残されており、弟子の素姓を窺い知ることができる（表 1） ${ }^{39)}$ 。そ れによると、弟子の出身地は多岐に及び、広範に亘ることが分かる。 明王太郎の棟梁職獲得に弟子が影響するのであれば、弟子の数が増 えるだけその機会が多くなる。明王太郎がそれを意図して弟子を取 ることは考え難いが、結果的に弟子を介在して棟梁職を獲得したこ とを、これら奉公人の中に想定してもよいであろう ${ }^{40)}$ 。出身地には、 特定の場所に偏る傾向が見られ、荻野周辺が最も多い。荻野という 地名に含まれる地域は比較的に広く、隣村の川入を含めて、合計七 件を数える。史料の残存は偶然の結果とは言うものの、それでも突 出しているだろう ${ }^{41)}$ 。

特定の土地に偏る傾向は弟子の出自だけではなく、明王太郎が手 掛けた在郷寺社の所在地にも現れている。江戸時代を通じて明王太 郎は五十件近い寺社の普請を請け負い、現地に赴いている ${ }^{42)}$ 。その 所在地は現在の厚木市域が最も多く、確認されているものだけで九 件を数える。居住地であった伊勢原市域の七件よりも多いのは、そ れなりの要因を想定すべきである。

弟子の出自も普請が行われた在郷寺社の所在地も、揃つて厚木市 域が最も多いことになる。これは、明王太郎が在地と地域的な広が りを持って関係性を構築させていたことを示唆している。つまり、 単純に個人と個人の結び付きが偶発的に起こって、弟子を取ったり 普請を行ったりしたのではなく、それら背景にはより大きな仕組み が組織され、その構造を通じて両者は繋がっていたと考えられる。

\section{（4）まとめ}

円通寺における弥市の働きは、弟子が新規の普請を明王太郎にも たらす確かな実例となった。更に、弟子は大工として普請に参加し、 明王太郎が棟梁職を獲得した在郷寺社での普請を助ける。このよう な側面から、明王太郎にとって弟子の存在は大きいものであったと 言えるだろう。弟子の出自は幅広く、各地から明王太郎の下に集まっ ており、それだけ在郷寺社の普請を獲得する潜在的な可能性を有し ていたことになる。また、弟子の出自は地域に偏る傾向が見られ、 それは普請が多く行われた地域でもあった。そのことより、明王太 郎は、個人的で偶発的なものではなく地域的で組織的な繋がりを有 していたことが想定された。

\section{4. 棟梁職の獲得と御師・檀家}

明王太郎が在郷寺社における棟梁職を獲得する過程で、地域との 結び付きに組織的な仕組みが構築されていることが想定された。そ こで注目されるのが、旺盛な行動力を有し、広範囲に亘って移動す る御師と、その先に居住する檀家を始めとした在郷民の存在である。

(1) 御師と檀家について

明王太郎と地域を繋ぐ役割を果たしたであろう媒体を、普請の際 に作成された「請負状」に見出すことができる。享和三年 (1803) 閏正月に、明王太郎は栗原村（伊勢原市三ノ宮）にある保国寺地蔵 堂の普請に関して請負状を取り交わす ${ }^{43)}$ 。そこには請負人の明王太 郎に連名して、<親類 $>$ の高尾佐仲と $<$ 口大 $>$ の近藤右近の名が加 えられている。共に、大山の麓に居住する御師である ${ }^{44)}$

大山山麓に居住する御師は各地に檀家を保有し、それより種々の 活動が展開される ${ }^{45)}$ 。御師が檀家を迴る檀迴りや檀家が大山を参詣 し御師へ立ち寄る坊入りなど、御師と檀家の双方が移動することに よって構成される動的な社会構造が成立していた。御師は各地に散 在する檀家を趈るために独自の経路を開発し、各地に名主などの協 力者を得て拠点（「定宿」と呼ばれる檀家宅）を持ち、そこを中心に 迴ると共に物や情報を集積させた。檀家は大山寺の参詣によって大 山と各地を結ぶ街道を成立させ繁栄させ、結果的に一大交通・通信 表 1 明王太郎が奉公人として受け入れた弟子

\begin{tabular}{|c|c|c|c|c|c|c|}
\hline 番号 & 年代 & 西暦 & 弟子氏名 & 出身村名 & 現地名 & 資料番号 \\
\hline 1 & 安永1.7 & 1772 & 庄助 & 中荻野村 & 厚木市中荻野 & $\mid\langle 172\rangle$ \\
\hline 2 & 安永4.4 & 1775 & 安右衛門 & 荻野村 & 厚木市下荻野 & $\langle 186\rangle$ \\
\hline 3 & 安永 4.7 & 1775 & 弥右衛門 & 七五三引村 & 伊勢原市上粕屋 & $\langle 187\rangle$ \\
\hline 4 & 天明1.2 & 1781 & 金左衛門 & 川入村 & 厚木市下川入 & $\langle 241\rangle$ \\
\hline 5 & 天明1.6 & 1781 & 吉左衛門 & 荻野村 & 厚木市下荻野 & $\langle 243-2\rangle$ \\
\hline 6 & 寛政 1.12 & 1789 & 右兵衛 & 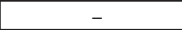 & - & $\langle 281-1\rangle$ \\
\hline 7 & 寛政2.3 & 1790 & 宇右衛門 & - & - & $\langle 283\rangle$ \\
\hline 8 & 寛政4.2 & 1792 & 宇兵衛 & 上荻野粕谷村 & 厚木市上荻野 & $\langle 284\rangle$ \\
\hline 9 & 寛政6.9 & 1794 & 乙吉 & 江戸本郷町三町目 & 文京区本郷 & $\langle 294\rangle$ \\
\hline 10 & 寛政8.4 & 1796 & 藤蔵 & - & - & $\langle 296\rangle$ \\
\hline 11 & 寛政10.8 & 1798 & 権左衛門 & 上荻野村 & 厚木市上荻野 & $\langle 298\rangle$ \\
\hline 12 & 寛政10.11 & 1798 & 伊左衛門 & 鴨宮村 & 小田原市鴨宮 & $\langle 299\rangle$ \\
\hline 13 & 享和 2.2 & 1802 & 藤兵衛 & 宮ヶ瀬 & 清川村宮ヶ瀬 & $\langle 314\rangle$ \\
\hline 14 & 享和 3.2 & 1803 & 要助 & 宮ヶ瀬 & 清川村宮ヶ瀬 & $\langle 320\rangle$ \\
\hline 15 & 享和3.4 & 1803 & 松五郎 & 大山別所 & 伊勢原市大山 & $\langle 322\rangle$ \\
\hline 16 & 享和 3.10 & 1803 & 小助 & 金目村 & 平塚市北金目 & $\langle 324\rangle$ \\
\hline 17 & 文化2.3 & 1805 & 岩治郎 & 国分村 & 海老名市国分北·南 & $\langle 334\rangle$ \\
\hline 18 & 文化8.6 & 1811 & 喜三郎 & - & - & $\langle 353\rangle$ \\
\hline 19 & 文政4.6 & 1821 & 藤五郎 & 品濃村 & 戸塚区品濃町 & $\langle 402\rangle$ \\
\hline 20 & 文政5.4 & 1822 & 口蔵 & - & - & $\langle 407-1\rangle$ \\
\hline 21 & 文政9.1 & 1826 & 高五郎 & - & - & $\langle 420\rangle$ \\
\hline 22 & 天保3.2 & 1832 & 定吉 & 平戸村 & 戸塚区平戸 & $\langle 437-2\rangle$ \\
\hline 23 & 天保10.9 & 1839 & 辰五郎 & 田中村 & 伊勢原市田中 & $\langle 465\rangle$ \\
\hline 24 & 嘉永 3.11 & 1850 & 常吉 & 荻野村 & 厚木市下荻野 & $\langle 532\rangle$ \\
\hline 25 & 文久2.6 & 1862 & 口吉 & $\begin{array}{lll}- \\
-\end{array}$ & - & $\langle 689\rangle$ \\
\hline
\end{tabular}

全て、手中家資料より作成した。出身者の多い順に、荻野周辺七件、大山周辺 三件（番号 3、15、23）、戸塚周辺武間（番号 19、22）、と続く。 
網が構築された。御師による檀家の保有は流動的であり、その権利 は売買や貸付の対象となった ${ }^{46)}$ 。その都度に御師と檀家の関係は更 新され、重層的に重なり合い、一つの地域に複数の御師が出入りす ることもあった。以上のように、御師と檀家は、檀迴りと坊入り（参 詣）という行為を通じて結び付きを強めていった ${ }^{47)}$ 。つまり、この 関係性に組み込まれる人間は情報を共有し、大山の存在を前提とし た共同体が組織されていくことになる。

このような御師の一人である近藤右近は、保国寺の普請における 請負状に<口入 >として記名されており、栗原村は大山の周辺域に ある村落ではあるものの、明王太郎と在郷寺社の間を仲介するとい う役割を担っている ${ }^{48)}$ 。また、御師が明王太郎と弟子を繋ぐ場合も あった。天保三年 (1832) 年二月に平戸村から入門した定吉の請状 には、<口入證人>として大山御師の佐藤大隅が連名している ${ }^{49)}$ 。 明王太郎と土地との繋がりという点において、御師が関連した事例 として注目される。

（2）波多野文右衛門と高尾佐仲

明王太郎は、武州多摩郡中藤村（武蔵村山市中央）にある山王宮 の普請を請け負う。文化九年（1812）十二月付けの棟札が上げられ、 そこには＜大願主＞として＜波多野文右衛門（後欠）＞と＜波多野 源八郎 (後欠) >の氏名が記録されている ${ }^{50)}$ 。また、文化七年 (1810) 六月付けの木積りは、明王太郎から<上中藤村波多野文右衛門様 $>$ と役人に宛てて作成されており、未尾に<右之通野取寸法荒増相記 シ差上申候以上＞とあることから、波多野文右衛門を代表とする村 方が木材を調達していたことも窥われる ${ }^{51)}$ 。つまり、波多野文右衛 門は依頼主側の中心的な人物として、この普請に関わっていた。こ の波多野文右衛門の名前は、他の寺社での普請で明王太郎が交わし た請負状にも記載されている。明王太郎は武州多摩群関戸村（多摩 市関总) にある金比羅宮の普請を請け負い、文化十年（1813）閏 十一月付けの請負状を作成している ${ }^{52)}$ 。宛先にある<井上林蔵様 $>$ が、この普請の依頼主となる。請負人として明王太郎の名前がある 他に、＜後見 $>$ と＜親類 $>$ に続いて＜世話人 $>$ として＜波多野文右 衛門 $>$ が連名している。また、明王太郎は武州戸倉新田（国分寺市 望倉）にある鎮守山王宮の普請を請け負い、文政四年（1821）九月 付けの請負状を作成している ${ }^{53)}$ 。それは、依頼主の<武州利倉新田 名主利倉郷左衛門様 $>$ に宛てられている。請負人としては、明王太 郎に続いて <後見 $>$ と $<$ 中藤村セ八人波多野文右衛門 $>$ が連名して いる。波多野文右衛門は、いずれも請け負う側の世話人として連名 している。つまり、中藤村山王宮普請では依頼主であった波多野文 右衛門は、関戸村金比羅宮や戸倉新田天王宮の普請では、請負人の 明王太郎の側で、世話人として関与して抢り、立場を違えているこ とが指摘できる。

このように、明王太郎が多摩地域一帯での普請を請け負い、仕事 を完了させることにおいて、波多野文右衛門が少なからず役割を果 たしていたことが分かる。波多野の家系は代々文右衛門を襲名し、「山 王前」の屋号を称した ${ }^{54)}$ 。秋葉山への参詣に際し、講元として地域 を代表する役回りでもあった ${ }^{55)}$ 。こように、村の世話人として働 いた人物であり、波多野家自身が大山御師と檀家の関係における定 宿となっていたことを考えてもよいであろう。しかし、明王太郎と 波多野文右衛門の間を具体的に取り持つ人間の存在も想定しなけれ ばならない。武州多摩群関戸村にある金比羅宮の普請で交わされた
請負状には、<親類＞として高尾佐仲が連名されている。それは依 頼主と明王太郎との契約を保証するための記入であり、この普請に おける高尾佐仲の仲介が想定される。高尾佐仲という御師は多摩地 域一帯を檀那場としており、多く檀家を保有しており、戸倉新田に も出入りしていた ${ }^{56)}$ 。関戸村の名主である井上林蔵の名前も、高尾 佐仲の檀家帳に記載されている ${ }^{57)}$ 。そのことからも、明王太郎の親 類で御師という高尾佐仲が、当地との仲介者になり得る状況にあっ たことが分かる。

以上のことから、明王太郎と当地を繋ぐ媒体として、御師の存在 が有力という見方が成立する。なお、関戸村金比羅宮や戸倉新田天 王宮での請負状や、武州多摩郡中宿村鎮守大神宮の普請に関連して 作成された文化九年 (1812) 十二月付けの書状には ${ }^{58)}$ 、明王太郎と 連名して<後見 $>$ の $<$ 和田衛守 $>$ が記録されている。和田衛守の名 前は中藤村山王宮の棟札にもあり、そこには＜権大工＞として記載 されている ${ }^{59)}$ 。その来歴は不明であるが、明王太郎を大工として補 佐していたであろうことが＜後見＞という立場より窥われる ${ }^{60)}$ 。

（3）長谷川長次郎と闕伽井坊

明王太郎は鎌倉郡下柏尾村（戸塚区柏尾町）にある王子大権現の 普請を請け負い、天保十五年（1844）四月二十三日付けの請負状を 作成する ${ }^{61)}$ 。そこには、明王太郎と連名して、<長谷川長次郎 >が

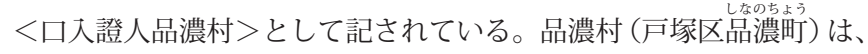
戸塚宿と保土ヶ谷宿の間に位置する街道沿いの村である。長谷川家 は代々に亘って村の名主を務め ${ }^{62)}$ 、当時は長次郎がその任にあたっ ていた ${ }^{63)}$ 。請負状にある肩書きより、長次郎が明王太郎と依頼主（王 子大権現）の間を取り持っていたことが分かる。また、これとは別 の普請が柏尾村で行われており (某神社)、明王太郎が請負人となる

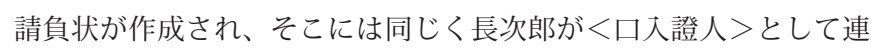
名している ${ }^{64)}$ 。

その三年後の弘化四年（1847）九月に、明王太郎は武州鶴見村（鶴 見区鶴覮中势）にある杉山神社の普請に関する請負状を作成する ${ }^{65)}$ 。 ここでは、<六人＞として＜保土ケ谷山下町銀次や直二郎 $>$ (横 浜市中区山町) が連名されている ${ }^{66)}$ 。また、<品濃坂下町長谷川 勘左衛門 $>$ 名前も見られ、ここでは＜引請人 >として記録されて いる。勘左衛門は、長次郎の跡を継いで品濃村の名主を勤めた ${ }^{67)} 。<\square$ 入人〉として明王太郎と杉山神社を仲介したのは山下町の直二郎と いうことになっているが、品濃村の勘左衛門が＜引請人 >として明 王太郎と直次郎の間を保証している。つまり、請負人の明王太郎と 依頼主の鶴見神社は、<口人人 $>$ の直二郎を介して $<$ 引請人 $>$ の勘 左衛門が結び付けたとしてよいであろう。

以上のように、戸塚や鶴見での普請を明王太郎が請け負うことに 関して、長谷川長次郎や銀次や直次郎がそれに寄与していたことが 分かる。特に、長谷川家の周旋が大きな契機となっていたことが想 定される。これら在郷民は土地の人間であるからして、普請を依頼 する側の在郷寺社との繋がりは当然ながら存在しょう。しかし、在 郷民と明王太郎が関係するには、なおその間を仲介する媒体の存在 を想定しなければならない。

明王太郎は保土ヶ谷にある天王宮の普請を請け負い、文政十三年 （1830）八月二十四日付けの請負状を作成する ${ }^{68)}$ 。そこには、明王 太郎と連名して、闕伽井坊が＜親類＞として記されている。䦠伽井 坊は大山に居住する御師であり、檀家を保有して檀廻りを行ってい 
た。この御師である闒伽井坊の活動の様子が、神奈川宿の石井本陣 で付けられていた日記に記録されている（表 2） ${ }^{69) 。 そ れ に よ る と 、 ~}$ 闕伽井坊は神奈川宿を度々に訪れ、＜宿内＞を廻り、＜配札＞など の活動を行っていたことが分かる。また、〈逗留〉していることか らも、神奈川宿には定宿を保有しており、それだけ土地との関係も 密接であったということになる。それは＜例之通＞という文言から も窥え、村側には䦥伽井坊の存在が日常的なものとして認知されて いたことの現れと読夕取れる。一方で、檀迴りは一つの村に限って 行われることはなく、村々を転々とするのが普通である。従って、 闒伽井坊も神奈川宿だけを檀那場とするのではなく、周辺地域にお いても活動していたであろう。明王太郎が請け負った天王宮がある 保土ヶ谷は、東海道沿いの宿であり、神奈川宿と戸塚宿の間に位置 する。この天王宮の普請を請け負う際の請負状に＜親類＞として連 名するのが閂伽井坊であることは、以上のような御師と檀家の関係 が前提となっているものと考えられる。また、柏尾村某神社の請負 状には、<口入 >の長谷川長次郎だけでなく、<親類 >として䦠伽 井坊が連名している。柏尾村も同様に、戸塚宿と藤沢宿の間にある 東海道沿いの村である。ここでも、御師が明王太郎と当地との間を 介する役割を果たしていたであろうことが指摘できるのである。

（4）まとめ

多摩地域周辺においては波多野文右衛門と高尾佐仲が、東海道沿 いにおいては長谷川長次郎・勘左衛門と閼伽井坊が、それぞれ明王 太郎と依頼主を仲介していることが想定された。御師は檀家場とし て面的な繋がりを地域と持ち、そこに居住する多数の憻家と結び付 きを得る。その中でも特に地域を代表するような有力な檀家が存在 し、地域の運営の担い手になると共に、情報の集積地としても機能 することになる。そこには、在郷寺社の普請に関するものも含まれ るであろう。このような仕組みでもって、最終的には明王太郎と在 郷寺社が関係付けられるに至る。

\section{5. おわりに}

明王太郎が広い範囲に亘って在郷寺社の普請を手掛けたという事 実を踏まえて、両者を繋ぐ媒体や仕組みを想定し、それを指摘する ことを目指してきた。考察の結果、その役割を果たしていた存在と して、各地から数多く取っていた弟子をまず挙げることができた。 弟子は、明王太郎を棟梁に推すだけではなく、大工としても普請に 参加し、造営での一役を担っていた。また、明王太郎が地域との結 び付きを得ることができた要因として、御師と檀家を主要な構成要 素とする巨大な組織網の存在も指摘することができた。その中にあっ て、御師や檀家がそれぞれ明王太郎の棟梁職の獲得に貢献した。明 王太郎が地域と面的な広がりを持って関係を構築させているように 見えるのは、御師や檀家の行動範囲がそれに反映していたためであ

表 2 石井順孝日記に記録された開伽井坊の檀廻りなど

\begin{tabular}{|c|c|c|c|c|}
\hline \multicolumn{4}{|c|}{ 日付 } & 内容 \\
\hline \multirow{3}{*}{ 文政9年 } & \multirow{3}{*}{1826} & 4月 & 16日 & 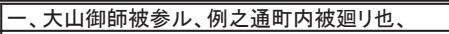 \\
\hline & & \multirow{2}{*}{ 12月 } & 7日 & 一、大山安 (閣)伽井坊泊り、 \\
\hline & & & 8日 & 一、大山安 (ママ)伽井坊逗留、宿内迴ル、 \\
\hline 文政10年 & 1827 & 6月 & 19日 & 一、大山神家赤加（閣伽）井坊来ル、例年之通、 \\
\hline 文政13年 & 1830 & 10月 & 10日 & 一、大山安(閭)伽井坊来リ、 \\
\hline \multirow{2}{*}{ 天保2年 } & \multirow{2}{*}{1831} & 4月 & 8日 & 一、大山安加 (閼伽)井坊来ル、出火見舞也、 \\
\hline & & 10月 & 23日 & 一、大山御師宿内相廻り候、 \\
\hline \multirow[t]{2}{*}{ 天保4年 } & \multirow[t]{2}{*}{1833} & 2月 & 17日 & 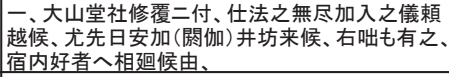 \\
\hline & & 9月 & 23日 & 一、大山アカイ(閼伽井)坊宿内配札、 \\
\hline
\end{tabular}

る。弟子の出自や普請が行われた寺社の所在がさまざまであるのも、 このような地域社会に特有の圈域が関係していると考えられる。

明王太郎の活躍は大山を中心に形成された地域社会と密接な関わ りを持つものであり、自らの存在が御師や檀家からなる共同性の内 部に位置付けられるほどに活動基盤は堅牢となり、より広い範囲で 活動を行うことができるようになっていったと言えるだろう。

注

1) 明王太郎に関しては、手中正「手中明王太郎と大工文書そして明王太郎敏 景」(『伊勢道中日記 旅する大工棟梁』、平凡社、1999.11) に詳しい。な 㧍、ここでの在郷寺社とは、幕府等の権力が直接的に関与しない程度の在 地の寺院を念頭に置いている。それは、本稿の目的を踏まえてのものであ り、例えば大山寺等は在郷寺社に含めない。

2)『相模国大山大工棟梁手中家資料所在目録稿』、神奈川県教育委員 会、1997.03。

3）手中家資料の中で見られる「棟梁職」という言葉には、広く大工棟梁とし ての職を示すために用いられている場合がある。例えば、明王太郎が上棟 式等を執り行うための許状を給わることを願い出た書状において、く私儀 代”大工棟梁職二而 $>$ 、(「乍恐書附を以奉願上候」手中家資料〈166〉) と あり、棟梁職が具体的な役職等を示すのではなく、一般的な語として用い られている。本稿でも、このような使用方法に倣う。

4) 本文で挙げた例を扱う主な論考として、高橋恒夫『気仙大工／東北の大工 集団』INAX ALBUM 6 (INAX 出版、1992.08)、伊藤好一「甲州大工仲間 の成立」(『甲斐史学』、甲斐史学会、1965.10)、坂本正夫『東和町誌』資 料編一 長州大工（山口県大島郡東和町、1993.03）、永井規男「播磨と淡 路の集住大工について」(『近世建築の生産組織と技術』、中央公論美術出 版、1984.10）などがある。また、高橋恒夫・菅谷真典「近世の在方集住 大工とその形態 一発生の背景・要因と大工集住率一」(『日本建築学会計 画系論文報告集』609、日本建築学会、2006.11）では、永井氏の論考を 受けて、集住大工という概念を軸に、全国の在地の大工集団を概括的に捉 えようとしている。

5) 永井規男「近世大阪大工宮屋とその営業形態」(『日本建築学会計画系論文 報告集』390、日本建築学会、1988.08）では、近世大工の活動範囲につ いて考察されている。そこでは、大坂に工房を構える市井の大工が、近江 や播磨・丹波、更には肥前・隠岐などの広範囲な地域で営業を行う上で、 施主との繋がりを得た要因を諸藩の大阪蔵屋敷や近江商人に求めている。

6) 河上信行「江戸時代の村落における寺社造営と名主の役割旧武蔵国多摩 郡の中小寺社造営」(『日本建築学会計画系論文報告集』435、日本建築学 会、1992.05）などでは、村落の中小寺社造営における施主の主体や役割 抢よびその変化を考察している。そこでは、名主が施主側と施工者側の両 者の立場を併せ持つ存在として位置付けられている。

7) 手中家資料には、近世における大工仲間等の存在を裏付ける史料は見られ ないが、明治時代に入ると大工仲間が結成されたようであり、それに関す る史料の数が増える。それは、大山自体が明治維新の前後に大きな変化を 経たことが要因と考えられるだろう。

8) 拙稿「近世相模国大山寺普請の内容的特質と明王太郎の行動及び役割につ いて」『日本建築学会計画系論文集』644、日本建築学会、2009.10。

9) 景直（-1786）は普請の途中に没しており、その後は景喜 (-1819) が仕 事を継承する (『伊勢道中日記旅する大工棟梁』、133 頁)。

10)二宮町 編『二宮町史』別編 寺社・金石文、二宮町、1994.03。

11) 明王太郎の一門については、拙稿「明王太郎と大山寺の関係について一江 戸時代に行われた大山寺普請において明王太郎が演じた役割一」（日本建 築学会関東支部研究報告、2007.03）の六節を参照のこと。

12)「大工弟子奉公人請状之事」(手中家資料〈172〉)。庄助は後に手中家の養 子となって明王太郎を襲名し、信景を名乗って棟梁職を継いでいる（手中 正『宮大工の技術と伝統 神興と明王太郎』、東京美術、1996.04、29頁)。

13）「川勾神社二宮大明神御宮下絵図」(手中家資料〈237〉)。

14)「相州二宮川勾神社拝殿下図」(手中家資料〈3327〉)、「二宮木寄控」(手 中家資料〈252〉)。

15)「川勾神社御普請諸留帳」(手中家資料〈254〉)。

16)川勾神社の資料では、延べ千十四人と記録されている（「二宮御普請中大 工杣木挽着到覚帳」川勾神社資料 $\langle 1121\rangle)$ 。

17) 日記の多くは、二宮町総務部総務課町史編さん係 編『川匂神社日記 (一) / (二)』二宮町史資料叢書 3/4（二宮町、1992.10/1993.03）に翻刻され 
ている。

18）『勾神社日記（一)』二宮町史資料叢書 3、4-6 頁など。

19）川勾神社社領の借地に関する証文の中には＜同断 忠七＞とあることから、 忠七は川勾神社社領を借地していたことが分かる（二宮町 編『二宮町史』 資料編 1 原始 古代 中世 近世、二宮町、1990.11、605-606 頁)

20) 周助には弟子の存在が確認でき、この地域において比較的に活発な活躍を 見せていたようである（二宮町総務部総務課町史編さん係 編『川勾神社日 記 (二)』二宮町史資料叢書 4)。また、川勾神社は天保二年（1831）に、

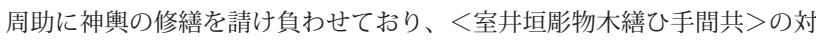
価として＜拾武両武朱＞が支払われた他、賃金による報酬を受け取ってい る（二宮町 編『二宮町史』別編 寺社・金石文、329-337 頁）。この時、周 助の下には既に佐吉がいたようであり、その名前が記録されている。

21)川勾神社は弘化四年 (1847) に、佐吉に神輿の新造を請け負わせている(「請 負申一札之事（御神輿新規仕立）」(川勾神社資料〈1146〉))。

22) 例えば、明治五年には越路大工の英之助が川勾神社より居宅の普請を請け 負っていることからも、その関係は長く続いていたことが分かる(「請負 申一札之事 (御居宅)」(川勾神社資料〈1207〉))。

23）『川勾神社日記（一)』二宮町史資料叢書 3、229 頁。書状には<当社明神 御普請御用之儀二付 $>$ という記述から始められており、新規の普請の依頼 が川勾神社から明王太郎に伝えられる。また、＜毎度二ノ宮明神絵図定而＞ と記述されており、川勾神社の明王太郎に対する近しい意識が読み取れる。

24）『川勾神社日記（一)』二宮町史資料叢書 3、230・235 頁。なお、明王太 郎宅へ訪問する前に、笹之院・小川隼人方・但馬方に立ち寄り、笹之院で は「実母」と対面している。従って、川勾神社との関係は明王太郎の個人 だけのものではなく、それを含めた大山にあると言える。

25）『川勾神社日記（一)』二宮町史資料叢書 3、243・246 頁。

26) 翌年の寛政十二年（1800）一月に明王太郎が新年の挨拶で川勾神社を訪 れるまで、明王太郎の名前が日記に書かれることはなく、実際に普請が行 われたかどうかを確認することはできない(『川勾神社日記 (一)』二宮町 史資料叢書 3、275 頁)。

27）『川勾神社日記（二)』二宮町史資料叢書 4、255-256 頁。

28) 差出人は、「氏子大工職」の「宗吉・藤五郎・藤右衛門」他三人の計六人である。 書状には、<明王太郎江御引受奉申上候上者、私共身分同人江続柄之者共 二而、数代之懇意依而者一同立入御普請垂木梁柱等二而茂、年未熟手伝等 皇し後年三至迄名目三茂相残、産神江対し冥加至極難有仕合奉存候、右 之通氏子大工一統心意奉申上度、願之通御聞済被成下置候八、金銭二難 替>とあり、比々多神社や明王太郎に対する意識が窥われる（伊勢原市史 編集委員会 編『伊勢原史市』。別編社寺、伊勢原市、1999.03、120 頁)。また、 続く<右之段御推察被成下明主太郎へ仰付被成下置候分一統難有仕合奉 存候 $>$ という記述から、弟子や氏子大工の行動が、明王太郎に指示された ものではなく、自主的なものであることも分かる。なお、「川勾神社日記」 には、＜免角大山明王太郎弟子氏主而立六主御座候>と記述されてお り、川勾神社もこれら弟子や氏子大工が行動していることを確かに認識し ていたことが知れる (『川勾神社日記（二)』二宮町史資料叢書 4、263 頁)。 29）『川勾神社日記（二)』二宮町史資料叢書 4、263-268 頁。

30) 明王太郎が、幟の柱に施すために描いたとされる彫刻の下絵が残るのみで ある (「(彫刻下絵)」手中家資料〈654〉)。

31)『秦野市史』第一巻 古代·中世寺社史料、秦野市、1985.03、661-662 頁。

32)「相渡申証文之事」(手中家資料〈605〉)。また、庫裏（客殿）に関する記 録も残していることから、どちらも手掛けた可能性がある(「(寺山村円通 寺客殿地割外)」手中家資料〈3838〉)。

33)「本宮御本社普請 - 寺山村円通寺普請手控」(手中家資料〈607〉)。

34) 蓑毛御師に関しては、西海賢二「相州大山講と袁毛御師」(『立正大学』57、 0985.03）などがある。

35)「手控（諸殿普請人足・費用控）」(手中家資料〈597〉)。

36)「沼見村天王宮御拝殿諸色控帳」(手中家資料〈467〉)。

37) 拙稿「明王太郎による大山近郷の寺社普請（保国寺を中心として）一明王 太郎の在郷寺社における普請役の獲得について : その 2-」『日本建築学会 関東支部研究報告集 II』2008 年度、日本建築学会、2009.02。

38)「相陽厚木天王御本殿工数諸色控帳」(手中家資料〈523〉)。

39）中荻野の庄助と平戸の定吉は、後に明王太郎を襲名し、それぞれ信景と景 元を名乗る (『伊勢道中日記 旅する大工棟梁』、133-135 頁)。

40) 江戸に住む弟子が、明王太郎を頼って援助を乞うという事例もある（『伊 勢道中日記 旅する大工棟梁』、151-152 頁)。具体的には、神田鍋町 (千 代田区神田淡路町）の弟子大工七蔵が品川（品川区南品川）にある海晏寺 の三社を請け負うも、手が付けられないことから明王太郎が江戸まで罷り 越している (「大堂御社坊扣」手中家資料〈674〉)。
41）この地域と関係が深かったことは、文政六年（1823）に作成された「荻 野新宿覚帳」(手中家資料〈411〉) という題された資料が残されているこ とからも指摘できよう。この類の資料に特定の地域名を冠する例は、他に なく特異である。土地を基準に据える資料として、檀家帳との質的な類似 性も指摘できるかも知れない。

42)『伊勢道中日記 旅する大工棟梁』、136-140 頁。

43)「請負申一札之事」(手中家資料〈318〉)。

44) 伊勢原市史編集委員会編『伊勢原市史』資料編続大山、伊勢原 市、1994.03、90-91・110 頁。

45) 最盛期である宝暦年間では、檀家の総数が百万を越えたと言う。御師や檀 家について考察した論考として、例えば、御師に関しては、田中宣一「相 州大山講の御師と檀家一江戸末期の談趈と夏山登择をめぐって一」(『日本 常民文化紀要』8- II 、成城大学大学院文学研究科、1982.03) などがある。 檀家に関しては、有賀密夫「大山門前町の研究—門前町の形成と御師の活 動と檀家圏一」(『地域研究』14、立正地理学会、1971.06) などがある。

46) 松岡俊「相模大山御師の檀家集積過程の構造 一村山八太夫直利と八大坊預 置檀家を中心として一」(『伊勢原の歴史』11、伊勢原市、1996.03）は、 檀家を「財」と見なす。財である檀家は、流通・交換・集積などの経済活 動を通じて、御師の間を流動する。

47) 松岡俊「コミュニケーション的行為としての「檀廻」一相模大山御師村山 八太夫の檀迴を中心として一」(『伊勢原の歴史』12、伊勢原市、1997.03)。

48）その他の請負状には、<親類 >として高尾佐仲・䦠伽井坊・長野仁大夫が、 <組総代 $>$ として成田庄太夫・和田主水・宮本平大夫が記載されている例 がある（手中家資料〈369/431/439/469/590/650〉）。

49)「大工職弟子奉公人請状之事」(手中家資料〈437-2〉)。

50)「山王大権現御社経営上棟祭祝詞」(手中家資料〈359 )。

51)「山王宮御社木積帳」(手中家資料〈347〉)。

52)「武州多摩郡関戸村」(手中家資料〈369〉)。

53) 国分寺市史編さん委員会 編『国分寺市資料集（III）』寺社・信仰・文芸関 係文書、国分寺市、1983.03、pp.177-178

54)『指田日記』、武蔵村山市教育委員会、1994.01。

55)杉本林志『狭山之渠』、狭山之染刊行會、1939.02、pp.108-111。

56)「相州武州十五里内檀家村乃写」（高尾家資料〈7〉）や「檀村附手控帳（常 陸国他)」(高尾家資料〈46〉)、「(檀廻帳) 戸倉新田」(高尾家資料〈80〉) などで当地の檀家が記録されている。

57)「檀那帳（武州宮沢新田他）」(高尾家資料〈2〉)

58)「入置申一札之事」(手中家資料〈358〉)。

59)「山王大権現御社経営上棟祭祝詞」(手中家資料〈359〉)。

60) 平山育男「国分寺市戸倉神社社殿と手中明王太郎について 国分寺市戸倉神 社の調査より $1 」(『 日$ 本建築学会関東支部研究報告集 II』2004 年度、日 本建築学会、2005.02）では、明王太郎が幼年であったことに注目している。

61）「請負申仮一札之事」(手中家資料〈485〉)。なお、表題に「仮」とあるが、 その内容は正式なものと比較して不足する所はなく、体裁は整っている。

62) 長谷川家に史料が残されており、その足跡を知ることができる(『横浜市 史料所在目録』第 8 集一戸塚区一、横浜市総務局、1983.03)。

63)「申渡覚」(長谷川昭一資料〈46〉)。

64)「右仕様御注文之通造作（柏尾村某社請負証文）」(手中家資料〈4743〉)。

65)「請負申一札之事」(手中家資料〈495〉)。

66)この他に<親類 $>$ と<組総代 $>$ の肩書きがあるが、そこに記されている名 前は省略されているために判断ができない。

67)「申渡之覚」（長谷川昭一資料〈53〉）では弘化二年（1845）十月付で受 取人が<品濃村名主長谷川長次郎殿 $>$ とあり、「申渡之覚」（長谷川昭一資 料〈54〉）では同年十一月付で受取人が＜品濃村名主長谷川勘左衛門殿> となっている。この間に、名主の代替わりが行われたことが想定される。

68)「請負申書附之事」(手中家資料〈431〉)。

69）青木美智男 監修『東海道神奈川宿本陣石井順孝日記 $1 / 2 / 3$ 』、ゆまに書 房、2001.05/2002.06/2003.05。

\section{附記}

・手中家資料の〈 〉は『相模国大山大工棟梁手中家資料所在目録稿』（神奈川 県教育委員会、1997.03）の整理番号に、川勾神社資料の〈〉は二宮町総務 部総務課町史編さん係 編『二宮町史資料所在目録 第 3 集』川勾地区・町外・ 補残（二宮町、1992.03）の整理番号に、長谷川昭一資料の〈〉は「県史」 編さんの際に作成された冊子（神奈川県立公文書館 蔵）の整理番号に、高尾 家資料の〈〉は伊勢原市役所が作成した冊子『高尾勲家文書（1）〜（13）』 の整理番号に、それぞれ準じている。 